\title{
Effect of Parenting Style on Bullying Behavior
}

\author{
Istiana Tajuddin \\ Department of Psychology \\ Hasanuddin University \\ Makassar, Indonesia \\ istiana84@gmail.com
}

\author{
Karina Alfisah Utami \\ Department of Psychology \\ Hasanuddin University \\ Makassar, Indonesia
}

\author{
Yassir Arafat \\ Department of Psychology \\ Hasanuddin University \\ Makassar, Indonesia
}

\begin{abstract}
Bullying is one of the most troubling events in many countries. However, at this time bullying behavior by the number continues to increase where most of them occur in the schools. This study aims describing the effect of parenting styles to the bullying behavior in Makassar based on actors (the bully), victim and bystander perspective. This research uses the qualitative method with a descriptive exploratory. The participants used in this research amounted to 11 people who are students of Pesantren X Makassar for junior that meet a certain criteria.
\end{abstract}

Keywords-bullying; parenting style; authoritarian parenting style

\section{INTRODUCTION}

Bullying is one of the most troubling events in many countries [1]. Based on a survey conducted by the Global School-Based Student Health Survey (GSHS) or a schoolbased global health survey around 2007 was found that around $40 \%$ of students aged 13-15 years in Indonesia reported that they had been physically assaulted during that year at their school [2]. A case report from KOMNAS from November 2009 found that 98 cases of physical violence, 108 sexual assaults and 176-child psychological violence occurred in the school environment [3]

The description shows that schools can be places where violent acts, whether physical or verbal. Supposedly, schools should be place for individuals to learn and shape their behavior toward a better direction. However, some schools not run in accordance with its purpose [4]. In fact, the violence and misconduct were perpetrated by the students and took place in schools that included general school criteria.

The facts show that the acts of violence occurring in schools that exist in Indonesia indicate the occurrence of behavior called bullying behavior. Olweus [5] mentions that bullying is an aggression or manipulation behavior that can be a physical, verbal or psychological abuse committed deliberately by a person or group of people who feel stronger or more powerful with the aim to harm a person or group of people who feel powerless. Bullying behavior, when viewed based on the context in which it occurs, can occur in different places, such as in an educational setting (such as school), workplace, home, neighborhood, playground, etc. Bullying as a complex phenomenon, of course, involves several components in it; the bully, the victim, and the bystander. The bully usually has aggressive, impulsive, popularity, and so on. Whereas victim usually has sensitive, quiet, neglected, and so forth [6].

Rigby describes bullying have a long-term impact on the bully, including being accused of being a criminal, and having a greater likelihood of being depressed than those who are not bully. Rigby also revealed that students who become bystander explain their feelings like feel happy to see it, there is a feeling guilty for not doing anything, there is a fear of suspecting will become the next victim, there is a shame, angry, and some who do not care about anything. The impact of bullying that has been described, of course, make us more aware of the dangers of bullying [7]

Bullying behavior occurs due to several factors, one of which is parenting style. Parenting style that are undemocratic and enjoy using violence in disciplining children can increase the risk of children engaging in bullying [8]. Anthony and Chinyelu [9] found that there was a positive relationship between parenting style and the tendency to engage in bullying behavior. Other studies have found that there are differences in parenting style of the bullies and the victims, where the bullies tend to get neglected parenting while the victim gets authoritative parenting [10]

Based on some symptoms described earlier, the issues in this study are the parenting styles that can affect the bullying behavior, either on the bullies, the victims, and bystander. Researchers are interested in this topic because there are differences influence of parenting style on the bullies and the victims but have not found a study that examines the three components of bullying, which are the bullies, the victims, and bystander. Based on the research background, the problem in this research is how the parenting styles affect the bullying behavior, both on the bullies, the victim, and the bystander.

The benefits of this research are theoretically expected to contribute to the development of psychology that discusses about bullying and the role of parenting which causes bullying behavior. This research can also be a reference for those who want to research about bullying. Practically, this study can also provide an information about parenting styles that can affect bullying behavior so that it can anticipate the children are not involved in the behavior. 


\section{LITERATURE REVIEW}

\section{A. Bullying}

Bullying is understood as an unbalanced interaction between a person or a group of people toward they who are weaker and cannot defend themselves. If this bullying continues, the power imbalance will increase [11]. Olweus [6] defines bullying as an activity in which individuals get negative actions repeatedly, time to time from other individual. Negative action refers to activities that are deliberately created or attempted to cause others to be injured or discomfort. Ken Rigby [5] describes bullying as a desire to harm that is shown by doing actions that make a person feel the pain done by someone or a group of people who are stronger and irresponsible and done with feelings of pleasure. Based on the descriptions of various experts, it can be concluded that bullying is an aggressive behavior perpetrated by a person or a group with feelings of pleasure and done repeatedly against others who are considered weak or helpless in order to harm, attack and cause others to feel physical discomfort and psychological.

Olweus [6] suggests there are several forms of bullying as follows:

- Verbally such as threatening, taunting, teasing or calling names.

- $\quad$ Physically, such as hits, pushes, kicks, or pinches.

- In the form of body gestures, such as showing ugly face of bad gestures, deliberately removing someone from a group, or refusing to obey or ignore the wishes of others.

Olweus [6] also revealed that the type of bullying consisting of two, as follows:

\section{- $\quad$ Direct Bullying}

This type of bullying refers to opposite, face-to-face (physical) contact, or verbal confrontation.

\section{- Indirect Bullying}

This type of bullying refers to the act of spreading rumors, alienating others from social activities, or scapegoating someone who often makes the victim himself unaware of who the bullies are, because the bullying is done indirectly.

Shidiqi \& Veronika [12] revealed that in bullying involves three components, someones who do the bullying, a person or group of people who see bullying behavior but do not engage in bullying, and the oppressed. Coloroso [12] mentions that the bullying actor is called the bully / bullies, then a person or group of people who see bullying behavior but doing nothing is called a bystander, and the oppressed is called the victim bullying (victim). While, Olweus (1993) emphasizes bullying components on the bully and victim [6].

Swearer and Susan (2011) mentioned several risk factors for bullying based on multiple context, such as individual factor (grade level, ethnic, religious orientation, socioeconomic status, socio-skills, academic achievement, sexual orientation, disability status), peers, family, and parental characteristics. [13]

The results found by Duncan [13] shows that bullies are usually from low-relation families, little warmth, presence of absent father, need high power, family dysfunction, aggressive behavior and authoritarian parents. Bully-victims usually come from families experiencing physical violence, domestic violence, powerless mother, inconsistent discipline, uninvolved parents, low-warmth, and negative environments. If the bully victim is male, then usually they are raised by an over protective mother, controlling too much, limiting, indulging, more involved, less warmth father figure, a critical parent, no caring parent, no figure parents. In addition, a hostile, opposing, loving, threatening, and controlling mother figure, while their father figure is unconcerned and controlling.

Sullivan [14] explains that among the various factors that cause bullying behavior, certain forms of parenting and family problems are the most important. Baumrind [15] mentions several types of parenting style, namely authoritarian, authoritative and permissive. However, in line with the development of science, Santrock (2003) then broke the permissive parenting into two forms: permissive-indulgent and permissive indifferent [15].

Swearer (2011) found that those from families who struggle against the use of drugs and alcohol, as well as those who experience physical or sexual abuse, are predicted to be the bullies or the bully-victims. Furthermore, those who bully by bluffing others constantly, are reported as children with family conflicts and lack of parental monitoring [13].

\section{B. Teenagers}

Individual age is said to have entered this period quite diverse, but Valentini (2006) mentions that the age of adolescents to the Indonesian people aged between 11 years to 24 years and unmarried status [16].

Erikson [17] points out that in this period teenagers are busy to find for their identities so they can explain who they are, then what is their role, whether they are adults or not. Erikson also added, teenagers will also try various roles and alternatives in the search for their identity. Successful teenagers will discover their new and acceptable identity, while those who do not make it through this period will experience confusion of identity [15].

Hurlock [17] reveals that teenagers are also a time where individual often unrealistic. They tend to see themselves and others in the context they want, not in the actual context, or in other words they are still egocentric.

\section{METHOD}

\section{A. Participants}

This research uses descriptive qualitative method to describe the parenting styles of the bullies, the victims, and 
the bystander. Subjects in this study amounted to 11 persons, including 5 the bullies, 3 victims, and 3 bystander).

Sampling was taken using purposive sampling technique. The characteristics of participants in this study are:

- The bullies

Man, aged 11-15 years, have been involved in being the bullies at least 3 times.

- The victims

Man, aged 11-15 years, have been involved in being the victims at 1 least times.

- Bystander

Men, aged 11-15 years, have been involved as bystander more than 1 times.

\section{B. Procedures}

Several stages done by researchers in retrieve the data. The first stage is to determine the sample research. The sample of this research is adolescents aged 11-15 years and sit in junior high school at a boarding school in Makassar. Sampling technique using purposive sampling. The second stage, the researchers asked for a list of names of students who had been involved in bullying to the school counselor. The researcher also requested the students' willingness to participate in the research by providing informed consent. The third stage is to conduct interviews based on interview guidelines that have been provided by researchers, observation and documentation (notes from school counselor). Interview guidelines are used based on factors that influence the occurrence of bullying, including the characteristics of parents based on the theory of Swearer and Susan (2011).

\section{Data collection and Analysis}

The first stage used is to make some questions based on the factors that influence the bullying using the theory of Swearer and Susan (2011). The second stage is interviewing the participants based on interview guidelines that have been made by researchers on 11 students who have been involved in bullying in various roles (the bullies, victims, bystander) that meet the characteristics. The third step is to analyze the data by using qualitative analysis model from Milles and Humberman in Sugiyono detailing 3 stages in qualitative data analysis i.e. data reduction, data display, and conclusion drawing / verification [18]. of a paragraph.

\section{RESUlts}

The results of research found that all subjects in this study generally get violence as a form of discipline on their behavior by their parents. These results show both on the bullies, the victims, and bystander.

\section{A. Description of the bullies perception of the parents parenting styles.}

Four of the five bullies acknowledged that their parents often use punishment in the form of physical violence (hitting, pinching, etc.) and some of them are still getting some physical violence as punishment until this day.

Interviewed to the bullies also found that three of them perceive one parent (mother or father) better than others. There are those who consider their mothers better than their fathers and vice versa. Two informants consider her mother better than her father and one informant thinks her father is better than her mother. They consider one parents is better than others in educating them, where one parent (father or mother) uses violence in educating, while the other does not use violence.

\section{B. Description of the victim's perception of the parents parenting style.}

Three victims perceive that their relationship with their parents is good and two of them tend to be close to their mothers and tell things to their mothers compared to their fathers. One of them, SH, was educated with violence by his parents (a form of punishment), similar to MS whose parents were disciplining by physical attack (punching), while RB was educated non-violently (SH, 1171-1183; SH, 120; RB, 271277; MS, 70-92). SH also ignored by his parents, which his parents are bringing $\mathrm{SH}$ to live with his grandmother when they know SH is stealing and his parents are embarrassed, otherwise $\mathrm{SH}$ is eager to live with his parents.

\section{Description of the observer's perception of parental parenting}

Based on the data obtained from the three informants who act as bystander (observer) in bullying behavior, then found the factors that become the supporting factor of students to be a bystander by giving a response as a defender, follower or outsider. All the participants have different response as bystander to bullying behavior. Informant $\mathrm{AD}$ is bystander defender, WD informant is bystander outsider and follower, while informant YD is bystander outsider. Although the responses given as bystanders differed, but all these three informants perceive the relationship with parents are going well with both parents, even the three claims to be close enough to the mother figure. These three informants are taught to be disciplined by their parents and when they are considered to be committing an offense or undisciplined, then their parents will punish them from scolding verbally (scolding) or punishing them with physical violence.

\section{DISCUSSION}

This research aims to know how the parenting styles effect bullying behavior, whether as the bullies, the victim, or the bystander.

Relationships with parents and descriptions of parenting styles can be seen through the statement of each informant in perceiving their parents. The study found that four of five informants were educated by punishment for disciplining children (if they violate parental rules) in the form of "nagging" or using words in high tone (angry) and with physical 
punishment in the form of beatings. Educating children in this way tends to lead to authoritarian parenting. Authoritarian parenting is a parenting pattern that emphasizes control and obedience of children. Parents stress the child to obey the standards set by the parent and punish severely if the child exhibits behaviors that are inconsistent with the child's wishes, and there is a tendency to be distant and less responsive to the child [19].

This is also supported by statements from informants regarding interest in the school also directed and determined by both their parents. This suggests that the parent of the bullies has a tendency to hold full control over the child (authoritarian parenting). This is in accordance with the results of research from Savi \& Triana [20] who found that authoritarian parenting in children encourages the emergence of bullying when he was in school. Sarwono [20] mentions that children who feel depressed in themselves, but do not have the ability to solve them well, tend to vent problems in the form of mischief to his friends, including in the form of bullying.

In addition, Duncan [13] states that bullying offenders usually come from families with low relationships, little warmth, presence of absent father, need high power, family dysfunction, aggressive behavior and authoritarian parents. In addition, the family as the first environment for each individual is also the best place for learning for the individual. If since childhood the individual has been introduced to violence either verbally or physically, then the individual will experience a learning process that will also imitate what their parents did to him. This certainly makes the participant who raised from a parent with such a character will have a tendency to be a bully [21]

The study also found that research participants who were victims of bullying generally received physical punishment from their parents (authoritarian parenting) and one of them was ignored by parents because they were embarrassed by their past behavior. This is in line with research that states that there are differences in parenting style of the bullies and the victims, where the bullies tend to get neglected parenting while the victim gets authoritative parenting [10].

The same thing happens to participants who choose to be bystanders where they have a good relationship with parents in general but they also often get punishment when making mistakes. Bystanders may generalize that anyone who is considered to be guilty can be punished in ways that they have understood, that is, with insults, with corporal punishment, or with social punishment (shunned).

Limitation of this study is when conducting interviews, the data obtained is not adequate because researchers have not been able to interview the significant others (parents) to strengthen the results of interviews with research participants. Suggestions for further researcher that are interested in further research on the effect of parenting style to bullying behavior, it is suggested to conduct more in-depth interviews to get richer information about the appropriateness of children's perception of their parenting styles with parenting actually implemented.

\section{CONCLUSION}

The study found that participants who became the bullies were children who were raised with authoritarian parenting. Their parents often use violence as a form of discipline against child behavior. They also assume that there are differences in parenting style between their parents.

The participants who act as the victim also get authoritarian parenting. When the child is guilty, the child will get verbal and physical punishment, and they also get parental neglect as a form of punishment for their behavior that is considered shameful parents.

Participants who choose to be bystanders generally perceive the relationship with both parents are good enough but they also often get punishment either verbally or physically.

\section{REFERENCES}

[1] E. Anthony, and N. Chinyelu. "Relationship between Parenting Styles and Tendency to Bullying Behavior among Adolescenst." Journal of Education and Human Development, Vol. 3,No. 1, pp. 507-521. 2014

[2] C. Fuensanta, S. Consuelo, R. Cecilia, and J.A Julian. "Adolescents and Preadolescents roles on bullying, and its relation with social climate and parenting styles." Revista de Psicodidactica. pp. 139-156. 2015

[3] W. D. Herlinda, W. D. (2015). PBB: 40\% Anak Indonesia Jadi Korban Bully di Sekolah. Internet : http://kabar24.bisnis.com/read/20150226/19/406778/pbb-40anak-indonesia-jadi-korban-bully-di-sekolah. 2015, [Dec 15, 2015]

[4] E.B. Hurlock. Psikologi Perkembangan, Suatu Pendekatan Sepanjang Rentang Kehidupan edisi kelima. Jakarta: Penerbit Erlangga. 2012

[5] Levianti. "Konformitas dan Bullying pada Siswa." Jurnal Psikologi, Vol.6 No.1 Universitas Esa Unggul, Jakarta. 2008

[6] G.O. Olga, M. Eva, O.R. Rosario. "Parenting Styles \& Bullying.The Mediating Role of Parental psychological aggression and physical punishment." Child Abuse \& Neglect, Vol. 51, pp. 132-143. Jan 2016

[7] D. Olweus. Bullying At School: What We Know and What We Can Do. Oxford: Blackwell Publisher. 1993

[8] D.E. Papalia, S.W. Olds, and R.D. Feldman Human Development 10th ed. New York: McGraw Hill. Companies, 2007

[9] A. Priyatna, A. Let's End Bullying: Memahami, Mencegah dan Mengatasi Bullying. Jakarta: PT. Elex Media Komputindo. 2010

[10] B. Rahmadara, B. Hubungan antara Pola Asuh Orangtua dan Peran-Peran dalam Perilaku Bullying pada Siswa Sekolah Dasar. Skripsi. Depok: Universitas Indonesia. 2012

[11] K. Rigby, K. Bullying in School and What To Do About It. Australia: AcerPress, 2007

[12] R.N. Sari and A. Muhammad, A. "Pemaafan dan Kecenderungan Perilaku Bullying pada Siswa Korban" Bullying. Jurnal Psikologi. Vol. 11. 2015

[13] J.W. Santrock, Life Span Development, Perkembangan Masa Hidup edisi kelima. Jakarta: Penerbit Erlangga. 2003

[14] D.N. Savi and N.E.D.S. Triana. "Hubungan Pola Asuh Otoriter Orangtua dengan Bullying di Sekolah pada siswa SMP.” Jurnal Indigeneous. Vol.13, No.1. pp.29-38, 2015

[15] B. Susanto. Pengertian Lembaga Pendidikan Menurut Para Ahli. 
Internet:

http://www.seputarpengetahuan.com/2015/03/pengertian-

lembaga-pendidikan-menurut-para-ahli.html 2015 [Aug 15, 2016]

[16] M.F. Shidiqi and S. Veronika. "Pemaknaan Bullying Pada Remaja Penindas." Jurnal Psikologi Kepribadian dan Sosial, Vol. 2, 2013

[17] Sugiyono. Metode Penelitain Kuantitatif Kualitatif dan R\&D. Bandung: Penerbit ALFABETA. 2009

[18] P.K. Smith, K. Keumjoo, and T. Yuichi. School Bullying in Different Cultures - Eastern and Western Perspective. United Kingdom: Cambridge University Press. 2016
[19] S.M. Swearer and M. Susan. "Risk Factors For and Outcomes Of Bullying and Victimization." Educational Psychology Papers and Publication. Lincoln: University of Nebraska. (2011).

[20] M.B.A. Tumon, "Studi Deskriptif Perilaku Bullying Pada Remaja." Jurnal Ilmiah Mahasiswa Universitas Surabaya, vol. 3,2014

[21] I. Usman. "Kepribadian, Komunikasi, Kelompok Teman Sebaya, Iklim Sekolah dan Perilaku Bullying." Jurnal Humanitas, vol.10. 2013

[22] V. Valentini, and Nisfiannoor. "Identity Achievement dengan Intimacy pada Remaja SMA." Jurnal PROVITAE, vol. 2, 2006 